\title{
The utility of blood D-dimer levels predicting the diagnosis of pulmonary embolism in cancer patients
}

\author{
Kanserli hastalarda kan D-dimer değerlerinin pulmoner emboli tanısını \\ öngörmedeki önemi
}

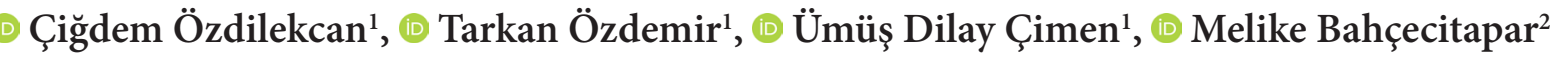 \\ ${ }^{1}$ University of Health Sciences Dr. Abdurrahman Yurtaslan Oncology Research and Training Hospital, Department of Pulmonology, Ankara, \\ Turkey \\ ${ }^{2}$ Hacettepe University, Faculty of Science, Department of Statistics, Ankara, Turkey
}

Cite this article as / Bu makaleye atıf için: Özdilekcan Ç, Özdemir T, Çimen ÜD, Bahçecitapar M. The utility of blood d-dimer levels predicting the diagnosis of pulmonary embolism in cancer patients. J Health Sci Med 2020; 3(3): 262-268.

\begin{abstract}
Aim: Cancer patients have increased risk of thrombosis. However, the use of D-dimer as a biomarker in malignancies, major surgery, infections and pregnancy was not recommended since D-dimer values were detected in high levels without PE. In this study, we aimed to evaluate the D-dimer values for the selected group of patients in the light of their clinical and demographic data and to reveal the utility of blood D-dimer measurements in cancer patients as a clinical decision rule. Also we aimed to define a new cut- off value for cancer patients who accurately diagnosed as pulmonary embolism.

Material and Method: This single -center retrospective and cross-sectional study was based upon patients' medical reports. The D-dimer values above $500 \mathrm{mcg} / \mathrm{dl}$ (>500 $\mathrm{mcg} / \mathrm{dl})$ were considered as positive results.

Results: One hundred twenty-eight patients (44 cancer patients (the case), 84 without cancer history (the control)) with accurate diagnosis of pulmonary embolism were included in the study. The mean blood level of D-dimer in the control group was $1729.3 \pm 2272.5 \mathrm{mcg} / \mathrm{dl}$ while the same parameters were calculated as $3326.9 \pm 3162.2 \mathrm{mcg} / \mathrm{dl}$ in the group with history of cancer indicating that the presence of malignancy caused a higher level of D-dimer levels. The most appropriate cut-off value in cancer patients was found as $1205 \mathrm{mcg} / \mathrm{dl}$ which had the sensitivity of $74 \%$, specifity of $64 \%$. This value corresponded to 2.41 times of the upper limits of the $\mathrm{D}$-dimer value according to our laboratory results.

Conclusion: For the diagnosis of PE the blood D-dimer values were absolutely a useful and a valuable parameter in cancer patients. We obtained a different cut-off value for D-Dimer in cancer patients which we think that will probably be a guidance for the future perspective of clinicians.
\end{abstract}

Keywords: Cancer, D-dimer, cut-off, pulmonary embolism

\section{ÖZ}

Amaç: Kanser hastaları artmış tromboz riskine sahiptirler. Tromboz biyobelirteçlerinden biri olan D-dimer'in malignite, major cerrahi, enfeksiyonlar ve gebelikte pulmoner emboli (PE) tanısında kullanılması önerilmemektedir, zira bu grup hastalarda gerçekte pulmoner emboli olmamasına rağmen değerler yüksek saptanmaktadır. Çalışmanın amacı, seçilen hasta grubunda D-dimer değerlerini klinik, demografik veriler ışı̆̆ında değerlendirmek, D-dimer ölçüm değerlerinin kanserli hastalarda klinik karar mekanizmasındaki önemini ortaya koymaktır. Ayrıca kanserli hastalarda PE tanısını öngörmede bir eşik D-dimer değeri saptamaktır.

Gereç ve Yöntem: Çalışma, tek merkezli kesitsel ve retrospektif hasta kayıtları göz önüne alınarak klinik demografik veriler eşliğinde yapıldı. D-dimer değeri $500 \mathrm{mcg} / \mathrm{dl}$ üzerinde pozitif sonuç olarak kabul edildi.

Bulgular: Toplam 128 kesin PE tanılı hasta; kanser-vaka $(n=44)$ ve kanser dışı hasta-kontrol $(n=84)$ çalıșmaya dahil edildi. Kontrol

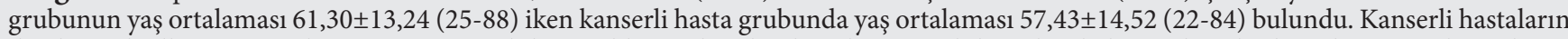
dağılımında ilk üç sırayı akciğer, meme ve abdominal kanserler almaktaydı. Kanserli hastalar ile kontrol grubu hastalar arasında D-dimer seviyeleri bakımından istatistiksel olarak anlamlı bir farklılık bulundu ( $\mathrm{p}<, 001)$. D-dimer kontrol grubunda 1729,3 $\pm 2272 \mathrm{mcg} / \mathrm{dl}$ iken kanser

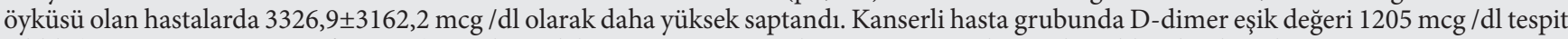
edildi (sensitivite: \%74, spesifite: \%64). Bu değer, laboratuvar üst sınır değerimizin 2,41 katına karşlık gelmekteydi.

Sonuç: Kan D-dimer değerleri kanserin eşlik ettiği olgularda klinik karar aşamasında oldukça değerli bir parametre olarak karşımıza çıkmaktadır. Kanser hastalarında farklı bir eşik değer saptadık ve bu durumun klinisyenlerin gelecekteki bakış açılarına rehberlik edebileceğini düşünmekteyiz.

Anahtar Kelimeler: Kanser, D-dimer, eşik değer, pulmoner emboli 


\section{INTRODUCTION}

The association between cancer and venous thromboembolism (VTE) which includes deep vein thrombosis (DVT) and pulmonary embolism (PE) was first described in 1865 by Trousseau (1). Cancer cells exert a prothrombotic effect on their microenvironment through direct and indirect mechanisms, which can manifest systemically and present clinically as thrombosis (2). The prothrombotic state characteristic of the malignant phenotype is the result of the interplay between the factors pertaining to Virchow's triad: hemostasis results from bed rest and vascular compression by the tumor mass; vessel injury is caused by intravasation of cancer cells. During the course of cancer the application of intravascular devices, and systemic long term therapies results with hypercoagulability due to mutual relationship among clinical risk factors, the tumor cell, and the host response (3) .

Patophysiology of cancer is associated with thrombin and fibrin formation directly through the release of procoagulants by neoplastic cells (e.g., tissue factor, cancer procoagulant, and, to a lesser extent, tumor mucins) and indirectly through the release of cytokines and the production of factor $\mathrm{X}$ activating cysteine proteases, mucinous glycoproteins, and circulating tissue factor bearing microparticles, which lead to the activation of platelets, leukocytes, and endothelial cells (4).

Cancer patients with $\mathrm{PE}$ are susceptible to poor prognosis, reduced survival rates, substantial healthcare costs. Also, these patients have a higher risk of recurrence when compared with patients with no cancer group. Cancer progression, as a first; thrombosis as a second leading cause of death in cancer patients. These group unfortunately experiences with more treatment complications such as bleeding, however better quality of life and decreased mortality is achieved with the prompt diagnosis of PE $(5,6)$.

It is almost certain that accurate diagnosis and treatment of pulmonary embolism in cancer patients is an important issue to prevent both mortality and morbidity rates. With an approach of pulmonary embolism (PE) suspicion and detection of biomarkers; unnecessary imaging procedures shall be reduced or quiet oppositely will encourage the physicians for further evaluation (7).

$\mathrm{D}$-dimer is an indicator of coagulation activation and fibrinolysis (8). The D-dimer becomes detectable after activation of the coagulation system with production and subsequent degradation of cross-linked fibrin (9). Several previous studies indicated that D-dimer was associated with risk of venous thromboembolism (VTE) in cancer patients and it is often used to rule out the diagnosis of pulmonary embolism (10).
However, some studies suggested that this biomarker was less accurate in cancer patients and cancer patients with normal D-dimer levels can present with pulmonary embolism (11). Therefore, D-dimer test positivity or negativity, cancer and PE association has got some unclear points as mentioned in the previous literature. In some circumstances such as malignancies, major surgery, infections and pregnancy, the use of D-dimer as a biomarker was not recommended since $\mathrm{D}$-dimer values were detected in high levels without PE (11).

Clinical decision rule (CDR) to predict $\mathrm{PE}$ in patients with malignancy needs potential explanations and further cut-off evaluations will improve clinical efficiency. As well as being a diagnostic biomarker for VTE, high $\mathrm{D}$-dimer values were mentioned to be associated with decreased survival and a predictor of treatment response with providing prognostic information in lung cancer patients $(8,12)$.

In this study, we aimed to evaluate the $\mathrm{D}$-dimer values in the selected group of patients in the light of their clinical and demographic data and to reveal the utility of $\mathrm{D}$-dimer value measurements in cancer patients as a clinical suspicion point. Also, to define a new cut-off value for cancer patients who accurately diagnosed as pulmonary embolism.

\section{MATERIAL AND METHOD}

\section{Study Design and Population}

This single-center retrospective and cross-sectional study was based upon patient medical reports.

This study was approved by the university /local human research ethics committee and all procedures performed in studies involving human participants were in accordance with the ethical standards of the institutional and/or national research committee and with the 1964 Helsinki Declaration and its later amendments or comparable ethical standards. The study was carried out with the permission of Ankara Dr. Adurrahman Yurtaslan Oncology Training and Research Hospital Ethics Committee (Permission granted: 12.2015, Decision no: 2015.351).

Between the years 2017-2019, the data of 128 patients with diagnosis of pulmonary embolism by the Chest disease department were collected. The demographic data, smoking status and rates (classified as current smoker, never smoker, former smoker) patient situation either hospitalized or outpatient during the course of diagnosis, initial symptoms during admission were recorded for all patients. Study population was divided into two groups regarding the accompanying illness. Patients those have had cancer were defined 
as "the case" and those who did not were taken as "the control" group. Cases with the malignant and nonmalignant disease history were separately evaluated. The data record of cancer patients were investigated according to the diagnosis (time of PE diagnosis), primary site of cancer, stage of the disease, tumoral dimension and the treatment approaches either surgery, chemotherapy or radiotherapy or combination of more than one treatment strategy. The verification of accurate diagnosis of PE was maintained for all patients (with either pulmonary computed tomographic angiography or ventilation perfusion scan). Patients were not allowed to be scanned by contrast enhanced tomography unless the renal functions were normal. In this circumstance scintigraphy was the safely preferred diagnostic method to verify the diagnosis.

\section{Exclusion and Inclusion Criteria}

Cancer patients who were suspected pulmonary embolism without definite diagnosis, hematological or coagulation diseases, hepatic and renal involvements, surgery or transfusion history within 3 months were excluded from the study. Patients with only history of solid tumors were included in the study. Control group selection was based on lack of cancer disease or history. Only the patients with accurate diagnosis of PE both in case and control group were included in the study. Patients with DVT without PE were excluded from the study. Most of the patients were performed venous doppler ultrasonography to identify the presence of DVT.

\section{Measurement of D-dimer Levels}

The blood samples were analyzed by immunometric system in coagulation device (SysmexR - Manufactured by Siemens company in Germany). The detected values between the interval $0-500 \mathrm{mcg} / \mathrm{dl}$ were considered as negative. The $\mathrm{D}$-dimer values above $500 \mathrm{mcg} / \mathrm{dl}(>500$ $\mathrm{mcg} / \mathrm{dl}$ ) were taken as positive results.

\section{Statistical Analysis}

The statistical analyses were performed in SPSS version 21.0 (IBM, Armonk, NY). Mann-Whitney U test was used to compare D-dimer values and ages for the patients who have cancer (the case) and those who do not (the control). Spearman correlation coefficients were calculated to assess the relationships between the potentially related variables. Kruskal-Wallis $\mathrm{H}$ test assessed the differences in D-dimer among more than two groups. In addition, groups were compared with chisquare test. Non-parametric methods were used because $\mathrm{D}$-dimer data could not be assumed to be symmetrically distributed. A p-value $<0.05$ was considered significant. The ability of $\mathrm{D}$-dimer scores to discriminate between patients with ('the case') and without ('the control') cancer in this study was investigated with receiver operating characteristic (ROC) analysis. The area under the ROC-curve (AUC) was calculated as a measure for the discriminative ability of D-dimer scores. The AUC indicates the probability that the D-dimer score correctly identifies the patient in case group. AUCwas found to be as 0.73 representing fair discrimination.

\section{RESULTS}

\section{Baseline and Clinical Characteristics}

128 patients [ 44 with cancer history (the case), and 84 without cancer history (the control)] were included in the study. In means of age there was no statistically significant difference between the cancer and the control group ( $p>0.05)$. No difference was found statistically about smoking between the cancer and control group ( $p>0.05$ ). The majority of non-smoker (never smokers+former smokers) patients were not with cancer diagnosis $(39 / 55,70.9 \%)$. When the initial respiratory symptoms for PE were questioned for all patients (chest pain, and dyspnea) the majority of patients were in the control group those had chest pain (39/42, 92.9\%). Also in the control group, $65.4 \%$ of patients experienced acute onset dyspnea. The distribution of cancer patients according to their primary cancer diagnosis was as follows: (lung 14 patients, breast 9 patients, colorectalpancreas and stomach 8 , lymphoma 5 , ovarian tumors 4 , extremity sarcomas 2 , brain tumors 2 )

The location of PE was analyzed and the majority of non-cancer patients (control group) had right-sided lung involvement (55.7\%). However, cancer patients nearly equally distributed for the right and the left-sided involvement (39.5\% and $40 \%$, respectively).

As shown in Table $\mathbf{1}$ there was a statistically significant difference between the cancer and the control group in means of hospital admission types $\left(\chi^{2}=33.51, \mathrm{p}<.001\right)$. A statistically significant difference was obtained between the gender and malignancy status $\left(\chi^{2}=5.02, \mathrm{p}<.05\right)$. Among the participants of the study $72.1 \%$ of the females were the control group and the remaining $27.9 \%$ were the cancer group. Also the rate of male patients who contributed the study was detected as $52.4 \%$ in control and $47.6 \%$ in cancer group. There was no statistically significant difference between the smoking and disease status $(\mathrm{p}>0.05)$. No significant correlation was found between the diagnostic method of PE (either with computed tomographic angiography (CTPA) or ventilation perfusion (V/Q) scan) and disease status of the study group $\left(\chi^{2}=1.35, \mathrm{df}=1, \mathrm{p}=0.24>0.50\right)$. Majority of patients were diagnosed with CTPA in cancer group (37\%) however majority non- cancer patients (46\%) were diagnosed with V/Q scan. 
Table 1. Basic characteristics of the study population

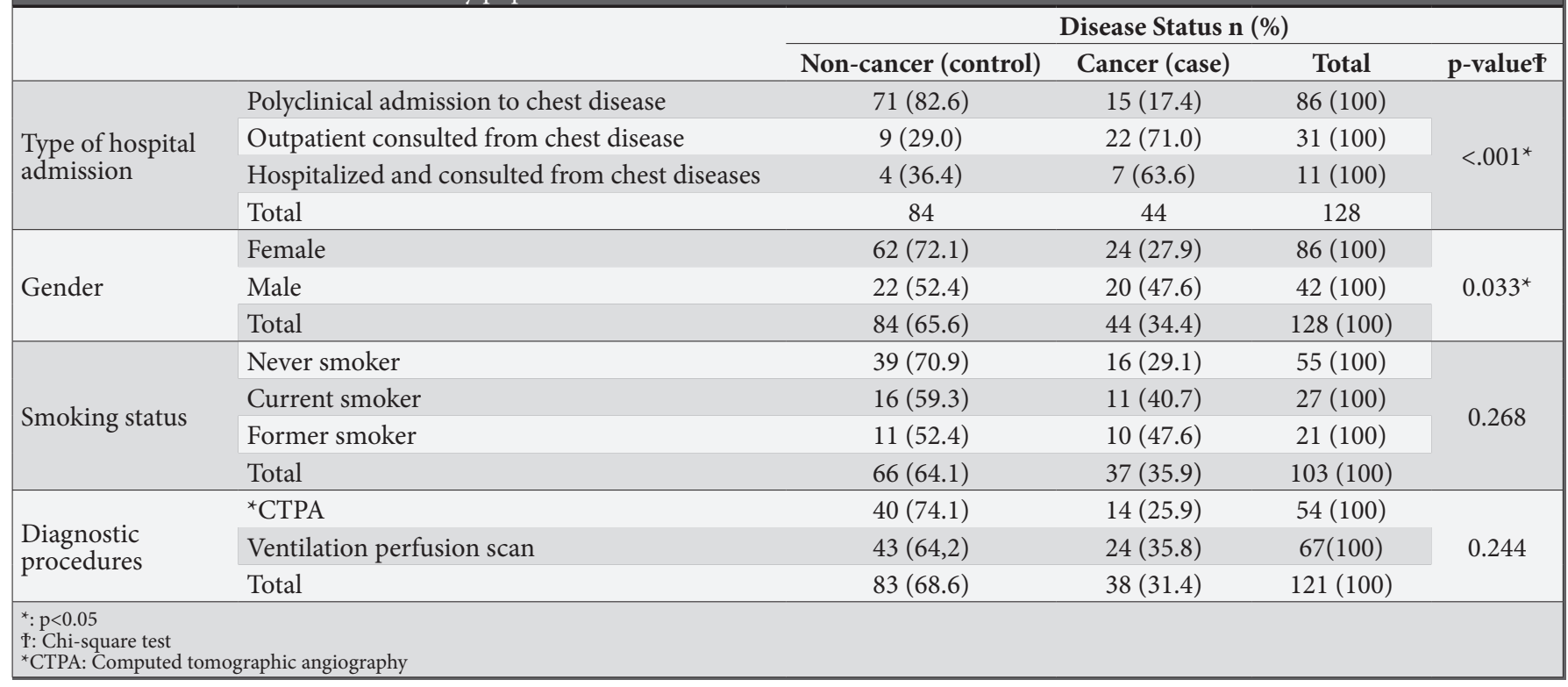

D-Dimer Outcomes in Cancer and Non-Cancer Patients There was no statistically significant difference between the cancer types in means of $\mathrm{D}$-dimer values $\left(\mathrm{r}_{\mathrm{s}}=0.231\right.$, $\mathrm{p}>0.05)$. When the association between stage of the primary lung cancer and the level of D-dimer values were analyzed there was a weak and the same direction correlation which was not statistically significant $\left(r_{s}=0.341, p>0.05\right)$. The dimension of the tumor and the level of D-dimer was also analyzed and there was a very weak and negative correlation between the short axis of the tumor and the $\mathrm{D}$-dimer values $\left(\mathrm{r}_{\mathrm{s}}=-0.164, \mathrm{p}>0.05\right)$. Similar correlation was found between the long axis of the tumor and the $\mathrm{D}$-dimer values $\left(\mathrm{r}_{\mathrm{s}}=-0.246, \mathrm{p}>0.05\right)$.

When the site of pulmonary thrombus location either in right or left lung was evaluated for the case and the control group with chi-square analysis, no statistically significant difference was obtained $\left(\chi^{2}=2.70, s d=2, p>0.05\right)$. Also no correlation was found between the $\mathrm{D}$-dimer values and the location of pulmonary embolus either in right, left or bilateral involvement $\left(\chi^{2}=7.70, \mathrm{sd}=2, \mathrm{p}>0.05\right)$.

There was a strong correlation between the cancer and the control group in means of blood D-dimer levels $\left(\chi^{2}=4.121, \mathrm{p}<.001\right)$. The mean blood level of $\mathrm{D}$-dimer in the control group patients was $1729.3 \pm 2272.5 \mathrm{mcg} /$ $\mathrm{dl}$, while the same parameters were calculated as $3326.9 \pm 3162.2 \mathrm{mcg} / \mathrm{dl}$ in the group with history of cancer indicating that the presence of malignancy caused a higher level of $\mathrm{D}$-dimer according to Mann Whitney $\mathrm{U}$ test as shown in Table 2. Lymphoma patients $(n=5)$ had a D-dimer level of 980-1210 mcg/dl (mean: $1133 \mathrm{mcg} / \mathrm{dl}$ ) similar to the results of non- cancer patients.
When the ROC curve was performed in order to determine the cut-off value of $\mathrm{D}$-dimer for the cancer patients, the AUC (area under curve) was calculated as 0.73 which indicates that the diagnostic value of the variable $D$-dimer was statistically significant $(p<0.001)$. The most appropriate cut-off value in cancer patients was found as $1205 \mathrm{mcg} / \mathrm{dl}$ which had the sensitivity of $74 \%$, specifity of $64 \%$ (Figure 1). This result also indicated that in cancer patients the level of D-dimer with the value of $1205 \mathrm{mcg} / \mathrm{dl}$ could verify the PE diagnosis with a possibility of 0.74 and could also predict the cancer patients without $\mathrm{PE}$ with a possibility of 0.64 . This value corresponded to 2.41 times of the upper limits of the $\mathrm{D}$-dimer value according to our laboratory results.

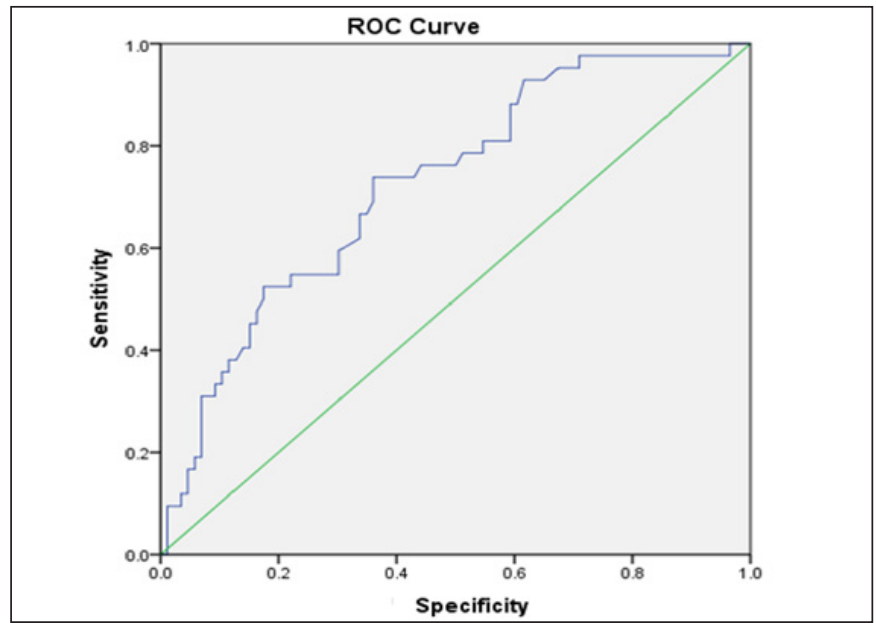

Figure 1. The ROC curve analysis predicting the value of D-dimer in cancer patients

Table 2. The level of blood D-dimer levels $(\mathrm{mcg} / \mathrm{dl})$ in the study group

\begin{tabular}{|lccccc|}
\hline Disease status & n & Mean \pm SD & Min & Max & p-value $\dagger$ \\
\hline Control (non-cancer) & 84 & $1729.3 \pm 2272.5$ & 190 & 15590 & \multirow{2}{*}{$<.001^{*}$} \\
Cancer patients & 44 & $3326.9 \pm 3162.2$ & 500 & 11920 & \\
\hline †: Mann Whitney U test & & & & \\
\hline
\end{tabular}




\section{DISCUSSION}

The findings of this present study demonstrated a strong correlation between the cancer and the non- cancer patient group in means of blood D-dimer levels.

Cancer itself and treatment course, immobility, agents used during treatments, surgical approaches and other comorbidities can all be underlying thrombogenic factors. For cancer patients, who present to emergency services timely prompt diagnosis is essential since the diagnosis and management of clinically suspected pulmonary embolism can influence the clinical outcomes. Primary symptoms of malignancy can also mimic the symptoms of PE which causes diagnostic difficulty (13).

Cancer patients are at risk for deep vein thrombosis as well as pulmonary embolism. The clinical presentation of these patients varies according to tumor type, grade and stage but the symptoms and signs in clinical practice may frequently be silent or often unspecific that can sometimes be under estimated. Biomarkers are important to reveal and reflect the activity of the coagulation cascade $(5,6)$. Historical aspect indicated that in some circumstances such as malignancies, major surgery, infections and pregnancy the use of D-dimer as a biomarker was not recommended since D-dimer values were detected in high levels without PE $(6,7)$. From the clinical aspect, detection of biomarkers will be helpful for early identification of cancer patients with risk of PE and focus on an anticoagulation treatment and a primary prevention and D-dimer as a biomarker even be a valuable biomarker for prediction of recurrent thromboembolic diseases in cancer patients after discontinuation of anticoagulation (14).

Several studies indicated that D-dimer values were associated with the risk of PE in cancer patients. Stender et al. (15) reported in their cohort study that positive preoperative $\mathrm{D}$-dimer value was associated with a higher cumulated incidence of postoperative deep venous thrombosis. Similarly, another study of Kodama J et al. (16) focused on 267 Japanese women with gynecologic cancer in their prospective study and found out that high plasma D-dimer levels on postoperative day 3 , were independent risk factors for postoperative VTE. In a study of Ferrori P et al. (17) detection of D-dimer levels prior to chemotherapy was reported as an important marker in lung cancer patients for VTE risk stratification helping in identifying individuals who could benefit from thromboprophylaxis.

Cosmi B et al. (14) concluded in their cohort study of 88 cancer patients with follow-up for 2 years, with a cut-off value of $500 \mathrm{ng} / \mathrm{mL}$ D-dimer values could be an important biomarker and independent risk factor for prediction of recurrent VTE in cancer patients after the discontinuation of anticoagulant treatment.
In the analysis of prospective Vienna Cancer and Thrombosis study (CATS) D-dimer was found to be a valuable biomarker for the prediction of VTE in cancer patients with a cut-off level of $1.44 \mu \mathrm{g} / \mathrm{ml}$ representing the 75th percentile of the total study population. D-dimer levels were measured by a quantitative latex assay (18).

Similar with our results Arpaia et al. (10) in their study conducted with 124 cancer patients with various entities found D-dimer cut-off with the value of $0.65 \mu \mathrm{g} / \mathrm{ml}$. Several studies also focused on different biomarkers in predicting VTE in cancer patients such as platelet counts, erythropoiesis stimulating agents, prothrombin fragment $1+2$ and fibrinogen.

It has been reported that cancer patients benefit from the prediction rules of clinical data as well as plasma $\mathrm{D}$-dimer levels that help to determine the risk of PE. Regardless of cancer type and stage plasma d-dimer values used to be reported as lower predictive value in cancer patients. Among the patients with hematological malignancies the level of plasma D-dimer was found to have low sensitivity in a previous report of Qdaisat et al. (19). Thus, they concluded that PE could occur in normal D-dimer values in these group of patients.

Our study group consisted of different system solid tumors with lymphoma group but other hematological cancers were excluded. In this lymphoma group the plasma level of D-dimer values were found similar as the non- cancer (control group). Lung cancer, breast and gastro intestinal tumors were the most cancer types in our study group. Previous studies reported that aggressive cancer types apparently were associated with a high thrombogenic potential, thus patients those developed VTE had poorer prognosis when compared with the patients without $\operatorname{VTE}(20,21)$.

A previous report of Qdaisat et al. (19) evaluated the cancer patients with suspected pulmonary embolism within the results of the American College of Physicians Guideline. In their large series including 380 patients, fifty-seven patients underwent unnecessary D-dimer evaluation, and 71 patients with negative $\mathrm{D}$-dimer test results underwent nonindicated CTPA. PEs were found in $6 \%$ of low-risk patients, $10 \%$ of intermediate-risk patients, and $25 \%$ of high-risk patients. They concluded that The ACP guideline had negative predictive value of $99 \%$ and sensitivity of $97 \%$ in predicting PE (13).

Both for our institution and the other centers those follow-up cancer patients it is a basic dilemma to avoid the patients from unnecessary further attempts including exposure to radiation. Physicians try to do their best for accurate diagnosis without delay, on the other hand try to protect the patients from hazardous radiation. As a clinical problem to be solved, we decided to obtain the utility of D-dimer in cancer patients for the diagnosis of PE and to observe the cut-off value which directs the physicians at least in the suspicion point of $\mathrm{PE}$. 
Our study had potential limitations; first the retrospective design and relatively small number of sample size with single center results did not allow us further evaluation and information. The number of patients revealed only the individuals either consulted or applied to Chest Disease Department of Ankara Oncology Hospital and diagnosed as PE accurately. Secondly the cancer types had heterogeneity with various type of cancers and with lack of the false negative or positive results of measurements. On the other hand, of our study results can remove the doubts especially about the importance and levels of D-dimer in cancer patients which was significantly higher than the control group.

D-dimer testing can be usefull for the diagnosis and follow-up of a variety of thrombosis based clinical conditions including disseminated intravascular coagulation (DIC), VTE, ischemic cardiomyopathy, stroke and thrombolytic treatments (22). Many types of D-dimer assays have been developed that can be broadly divided into 3 categories. (a) ELISAs, which are quantitative and highly sensitive, but time consuming; (b) latex-based immunoassays performed manually with visual inspection that are semiquantitative and less sensitive than the ELISA, but more rapid; and (c) latexbased automated assays with immunoturbidimetric readings. The latter are quantitative, as sensitive as the ELISA, and very rapid and can be performed on a regular coagulometer (23).Our D-dimer essay method was based latex enhanced immunoturbidimetric essay which is less sensitive than ELISA but more rapid.

\section{CONCLUSION}

In conclusion, blood $\mathrm{D}$-dimer values were absolutely a useful and a valuable parameter in cancer patients for the diagnosis of PE. With the cut-off value of $1205 \mathrm{mcg} / \mathrm{dl}$ and the 2.41 times of the upper limit of measured D-dimer values can have validity to predict $\mathrm{PE}$ in various cancer patients. These results can help to distinguish the need for further evaluation in cancer patients with a simple blood test. Future prospective trials are needed with large data samples which can lead a better understanding about the cut-off values of $\mathrm{D}$-dimer indicating the false positive and negative results.

\section{ETHICAL DECLARATIONS}

Ethics Committee Approval: The study was carried out with the permission of Ankara Dr. Abdurrahman Yurtaslan Oncology Training and Research Hospital Ethics Committee (Permission granted: 12.2015, Decision no: 2015.351).

Informed Consent: Because the study was designed retrospectively, no written informed consent form was obtained from patients.
Referee Evaluation Process: Externally peer-reviewed.

Conflict of Interest Statement: The authors have no conflicts of interest to declare.

Financial Disclosure: The authors declared that this study has received no financial support.

Author Contributions: All of the authors declare that they have all participated in the design, execution, and analysis of the paper, and that they have approved the final version.

\section{REFERENCES}

1. Trousseau A. Phlegmasia Alba Dolens. Clinique medicale de l'Hotel-Dieu de Paris, London: New Syndeham Society. 1865; 3: 695-727.

2. Kuderer NM, Ortel TL, Francis CW. Impact of venous thromboembolism and anticoagulation on cancer and cancer survival. J Clin Oncol 2009; 27: 4902-11.

3. Zwicker JI, Furie BC, Furie B. Cancer-associated thrombosis. Crit Rev Oncol Hematol 2007; 62: 126-36.

4. 4.Donnellan E, Kevane B, Bird BRH, et al. Cancer and venous thromboembolic disease: From molecular mechanisms to clinical management. Curr Oncol 2014; 21: 134-43.

5. Jeong J, Jeong MJ, Choi K, et al. Clinical outcomes of comorbid cancer patients with venous thromboembolism: A retrospective, single-center study in Korea. Medicine (Baltimore) 2019; 98: e17181.

6. Khorana AA, Francis CW, Culakova E, Kuderer NM, Lyman GH. Thromboembolism is a leading cause of death in cancer patients receiving outpatient chemotherapy. J Thromb Haemost 2007; 5: 632-4.

7. Khorana AA, Francis CW, Culakova E, Lyman GH. Risk factors for chemotherapy-associated venous thromboembolism in a prospective observational study. Cancer 2005; 104: 2822-9.

8. Zhou YX, Yang ZM, Feng J, Shan YJ, Wang WL, Mei YQ. High plasma D-dimer level is associated with decreased survival in patients with lung cancer: A meta-analysis. Tumour Biol 2013; 34: 3701-4.

9. Kupp S, Pöss J. Importance of biomarkers in pulmonary embolism. Internist (Berl) 2019; 60: 571-7

10. Pabinger I, Thaler J, Ay C. Biomarkers for prediction of venous thromboembolism in cancer. Blood 2013; 122: 2011-8.

11. Qdaisat A, Wu CC, Yeung SJ. Normal D-dimer levels in cancer patients with radiologic evidence of pulmonary embolism. J Thromb Thrombolysis 2019; 48: 174-9.

12.Ge LP, Li J, Bao QL, Chen P, Jiang Q, Zhu LR. Prognostic and predictive value of plasma $\mathrm{D}$-dimer in advanced non-small cell lung cancer patients undergoing first-line chemotherapy. Clin Transl Oncol 2015; 17: 57-64.

13. Qdaisat A, Yeung SJ, Variyam DE, et al. Evaluation of cancer patients with suspected pulmonary embolism: Performance of the American College of Physicians guideline. J Am Coll Radiol 2020; 17: 22-30.

14. Cosmi B, Legnani C, Cini M, Guazzaloca G, Palareti G. The role of $\mathrm{D}$-dimer and residual venous obstruction in recurrence of venous thromboembolism after anticoagulation withdrawal in cancer patients. Haematologica 2005; 90: 713-5.

15. Stender MT, Frøkjaer JB, Larsen TB, Lundbye-Christensen S, Thorlacius-Ussing O. Preoperative plasma D-dimer is a predictor of postoperative deep venous thrombosis in colorectal cancer patients: A clinical, prospective cohort study with one-year follow-up. Dis Colon Rectum 2009; 52: 446-51. 
16. Kodama J, Seki N, Masahiro S, et al. D-dimer level as a risk factor for postoperative venous thromboembolism in Japanese women with gynecologic cancer. Ann Oncol 2010; 21: 1651-6.

17.Ferroni P, Martini F, Portarena I, et al. Novel high-sensitive D-dimer determination predicts chemotherapy -associated venous thromboembolism in intermediate risk lung cancer patients. Clin Lung Cancer 2012; 13: 482-7.

18. Ay C, Vormittag R, Dunkler D, et al. D-dimer and prothrombin fragment $1+2$ predict venous thromboembolism in patients with cancer: results from the Vienna Cancer and Thrombosis Study. J Clin Oncol 2009; 27: 4124-9.

19. Qdaisat A, Soud RA, Wu CC, et al. Poor performance of D-dimer in excluding venous thromboembolism among patients with lymphoma and leukemia. Haematologica 2019; 104: 265-8.

20.Dentali F, Ageno W, Pierfranceschi MG, et al. Prognostic relevance of an asymptomatic venous thromboembolism in patients with cancer. J Thromb Haemost 2011; 9: 1081-3.

21.Timp JF, Braekkan SK, Versteeg HH, Cannegieter SC. Epidemiology of cancer-associated venous thrombosis. Blood 2013; 122: 1712-23.

22. Armando Tripodi. D-Dimer Testing in Laboratory Practice Clinical Chemistry 2011; 57: 1256-62.

23. Froehling DA, Daniels PR, Swensen SJ, et al. Evaluation of a quantitative $\mathrm{D}$-dimer latex immunoassay for acute pulmonary embolism diagnosed by computed tomographic angiography. Mayo Clin Proc 2007; 82: 556-60. 